ISSN: $2690-8220$

\title{
Using Military Strategy to Teach Marketing Strategy: Preparing Students for the Global Economy
}

\author{
Diane M. Phillips \\ Saint Joseph's University \\ Jason Keith Phillips \\ West Chester University
}

\begin{abstract}
Young Americans have a distinct knowledge deficit regarding history, culture, and geography (Hess, 2008; National Geographic, 2006) that is so severe that they "lack even the most basic skills for navigating the international economy" (National Geographic 2006, p. 7). This manuscript provides an outline for a marketing strategy course that is designed to address these deficits. By applying concepts from military strategy to marketing strategy - with a strong emphasis on historical and geographical literacy - students achieve a deeper understanding of marketing strategy and a more flexible use of strategic principles across a variety of contexts, time frames, and national boundaries.
\end{abstract}

Keywords: global awareness, military strategy, marketing strategy, historical literacy, geographical literacy 


\section{If you do not know others and do not know yourself, you will be in danger in every single battle. Sun Tzu, Art of War}

\section{Historical and Geographical Illiteracy In American Students}

In business schools across the United States, many students lack the basic historical and geographical literacy they need to be effective in an increasingly global marketplace. Although there is universal agreement that global issues are becoming ever more important to the marketing discipline and more business-specific international elements are being added to the business curriculum, it is unclear whether students possess the skills and knowledge necessary to successfully apply these concepts in a global environment. How can students fully appreciate an outstanding example concerning doing business in China when they don't have any conception of China's history, don't have any idea who Mao Tse-Tung was, and can't even find China on a world map? Importantly, how can students then graduate and successfully conduct business in a global marketplace when they are essentially historically and geographically illiterate?

The undergraduate marketing strategy course described herein incorporates military strategy to teach marketing strategy while at the same time improving student historical and geographical literacy. This course has been used, either in its entirety or via its major components, at three separate institutions of higher learning: a midsized state university, a small private university, and an Ivy League university. It has resulted in students who have a deeper level of learning and understanding of the complexities of marketing strategy.

\section{The Problem}

The problem of student historical and geographical illiteracy is impossible to ignore. Lest we believe that there isn't a problem, anecdotal evidence and prior research both clearly illustrate that many American business students lack the historical, cultural, and geographical knowledge needed to fully comprehend the global examples and case studies used every day in undergraduate business classes. Some examples of student historical and geographical illiteracy include:

- During a discussion of historical issues related to World War II and the current product offerings by several firms, a student (who had one of the highest grades in the class) admitted that she was never sure about what happened at Pearl Harbor... did the US bomb Japan or did Japan bomb the US?

- During discussions regarding study abroad offerings for undergraduate business students, students frequently ask nonsensical questions, such as whether they speak English in Australia, where New Zealand is located, and whether they speak Swedish in Switzerland.

- In a recent convenience sample of 15 graduating seniors, none knew who George Armstrong Custer was or the impact of his hubris on his life and career.

Although we as business educators may wish that these were isolated and atypical examples, the sad truth is that they are representative of many current business students. A recent study of 17year-olds (our soon-to-be college freshmen) revealed a disturbing lack of international historical knowledge. Some findings of this study (Hess, 2008) include: 
- $40 \%$ were unable to correctly identify that World War I occurred between 1900 and 1950

- $26 \%$ did not know that Christopher Columbus sailed for the New World sometime before 1750 ,

- $23 \%$ were unable to correctly identify Adolf Hitler, and

- $18 \%$ did not know that the major enemies of the U.S. during World War II were Germany and Japan.

Americans aged 18-24 fared little better with regard to geographical skills and knowledge. A study by National Geographic, Roper Public Affairs (2006) found that most young adults demonstrated very limited understanding of the world and also do not place sufficient importance on basic geographic knowledge. Some specific findings regarding the global awareness of young Americans include:

- $63 \%$ were unable to find Iraq or Saudi Arabia on a map of the Middle East, $75 \%$ could not find Iran or Israel, and $44 \%$ could not locate even one of these countries,

- $88 \%$ could not locate Afghanistan on a map of Asia, and

- $54 \%$ did not know that Sudan is in Africa and $40 \%$ did not know that Rwanda is in Africa

- $70 \%$ were unable to find North Korea and $63 \%$ did not know that its border with South Korea is the most heavily fortified in the world, and

- $31 \%$ were unable to locate China on a map.

The conclusion reached by the researchers was that young Americans are unprepared for an increasingly global future and that "many lack even the most basic skills for navigating the international economy or understanding the relationships among people and places that provide critical context for world events" (National Geographic, 2006: 7).

One possible reason for this knowledge deficit regarding geography is that as many as $49 \%$ of those surveyed stated that they had never had a class devoted entirely to geography at any time between the sixth grade and their senior year in high school (National Geographic, 2006). In fact, the U.S. is the only major developed nation where it is possible to get to the university level without ever having taken a course in geography (Carr, 2005). Indeed, a large proportion of students are unable to accurately place major countries on the globe and are also unable to place important world events like World War II on a timeline (Davis, 2005; Gross, 1999). These studies suggest that a substantial number of the students currently in American undergraduate marketing classes are both historically and geographically illiterate.

In recent years, American business schools have heeded the call from the business community for more relevant training in their curricula. For example, to deepen cultural and language competencies, some schools have emphasized foreign language study and study abroad experiences (Walker, 2009; Wright \& Larsen, 2012). Indeed, 71\% of AACSB accredited schools now require language training and $36 \%$ now require an overseas experience (Walker, 2009). Other schools have attempted to deepen socio-cultural understanding by emphasizing service learning experiences and civic engagement projects (Berry \& Workman, 2007). Even the U.S. Army has called for greater cross-cultural and geographical understanding on the part of 
members of the armed forces to develop a "shared understanding and enthusiasm" when they go abroad (Thompson \& Grubbs, 1998).

Business executives need this base of knowledge in order to be successful decision makers (Kantrow, 1986). Indeed, many executives find that they need to better refine their understanding of business strategy long after they leave business school. Some have sought out the teachings of the ancient Chinese military strategist, Sun Tzu and his writings in The Art of War. Sun Tzu and his followers utilized historical examples to develop and refine military strategy and philosophy (Tsang \& Lee, 2002). These "timeless" principles have provided business executives with a variety of strategies and although this book was written 2,500 years ago, it is still judged to be one of the most influential business books of all time (James, 2013).

Preparing students for the uncertain global business environment requires not simply knowledge or understanding of a list of useful business strategies. Instead, it requires integrative thinking, consideration, and flexible application of a set of strategies across a variety of different settings and in a variety of different contexts.

While university educators can do little to increase the proportion of students who are adequately exposed to geography and history before starting their university education, the fact remains that business students need this knowledge to successfully compete in the global economy (Kantrow, 1986). University-level educators must therefore take steps to ensure that students are provided with opportunities to obtain this necessary knowledge (Davis, 2005). To be competitive in the global economy, it is imperative that our students demonstrate such competencies. To be sure, students who are educated in non-US business programs have these competencies (Morin, 2012). It is our contention that business programs are currently not putting enough emphasis on the broader, contextual knowledge students need to be competitive. That is, students are being taught extensively about the "trees" but know little of the "forest" of which the trees are but a part.

\section{The Intersection of Liberal Arts and Business Studies}

To date, a considerable amount of academic effort has been expended on incorporating business and professional studies into the liberal arts curriculum (Ahmed \& Krohn ,1994; Chung, Molnar, \& Gilbertson, 2011; Ewest \& Kliegl 2012; Hutton, 2006; Stewart 2004). The arguments for the inclusion of business studies in the liberal arts curriculum range from necessity (i.e., liberal art majors need business skills in life) to survival realities for some liberal arts disciplines, specifically, the large number of students enrolling in undergraduate business programs and the decline in some liberal arts academic fields including languages/literatures, sociology, economics, geography, and history (Brint, Proctor, Mulligan, Rotondi, \& Hanneman, 2012).

Studies on the integration of liberal arts into the undergraduate business curriculum are less common. It is important to provide a historical context for the time periods and theories presented in management courses because by not doing so, educators miss an opportunity to develop student abilities to think, both critically and reflectively, about the past and its implications for the present (Kantrow, 1986; Petkus, 2010; Smith, 2007). Some experts argue that most undergraduate programs are too narrow and fail to require students to question assumptions, think creatively, or understand the place of business in a larger context (Colby, 
Ehrlich, Sullivan, \& Dolle, 2011; Stewart, 2010). In a comprehensive, multi-year study of the impact of liberal arts education on American competitiveness on the global stage, the prestigious American Academy of Arts \& Sciences found that American students need a stronger grounding in a variety of liberal arts disciplines, such as social studies, languages, and history (2013). This stronger grounding would help to "allow citizens to participate meaningfully in the democratic process - as voters, informed consumers, and productive workers" (American Academy of Arts \& Sciences, 2013). To train business students to more effectively participate in the global economy, topics such as literature, history, mathematics, and the social sciences should be more thoroughly integrated throughout undergraduate business programs (Colby, et al., 2011; Kliegl \& Weaver, 2012; Petkus, 2010; Stewart, 2010).

\section{The Liberal Arts General Education Requirements: Missing the Beat}

General education requirements (GenEds) are a part of nearly all college/university curriculums in the U.S. Unfortunately, these GenEds often fail to provide any context for business students to adequately understand how the material they are learning is of any practical importance. Further, most colleges and universities continue to provide knowledge to students via academic "silos" in which little or no effort is made at integrating the material with other silos.

As a result, rather than as a source of important knowledge, students generally look at their GenEds as something they have to "get through" (Stewart, 2010). Unfortunately, GenEds are regarded as having very little practical value by business students to their future careers or personal welfare. Faculty advisors often exacerbate this problem by marginalizing the importance of these classes to students. Admittedly, this marginalization is sometimes justified as the specific courses required to meet GenEd requirements are sometimes picked by a faculty committee based on staffing and a variety of other issues instead of their usefulness to students (Davis, 2005; Stewart, 2010). Together, these factors have resulted in the problem of historical and geographical illiteracy becoming institutionalized in higher education.

The difficulty in integrating liberal arts and business is by no means a new problem. Over fifty years ago, a study which consisted of interviews at approximately 70 undergraduate colleges and universities across the U.S. revealed remarkably similar concerns. Specifically:

...the work which students do in liberal arts subjects appears to have little relation to their studies in business... and not infrequently consists of a certain number of courses to be gotten out of the way as quickly and painlessly as possible... the fact remains, and this is all but universally admitted, the liberal arts courses mean little or nothing to a very large number of undergraduate business students (Pierson, 1959: 164-165).

This research, conducted in the late 1950s, also revealed that not one of the hundreds of people interviewed expressed any concern that undergraduate business students were being exposed to too little business information and, in fact, a large number of those interviewed expressed a concern that undergraduate business students were instead not being exposed to enough liberal arts material (Pierson, et al., 1959).

Over 70 years ago, Devane (1943) argued that the function of a "good college" is three-fold: (1) to provide a general education broad in scope, 
(2) to arrange programs of moderate concentration which will give the student a sense of mastery in a particular field, and

(3) to bring him (the student) to that point of maturity at which he is capable of genuinely independent work (Devane, 1943).

U.S. business schools are clearly accomplishing the second function and, by addressing the first and third functions, we contend that they could also directly impact the lives of students by preparing them for competing in the global economy.

\section{Use of Military Strategy in Business}

Applying military strategy to business is certainly not new. Indeed, in order to aid the process of thinking and planning a firm's competitive strategy, some academicians have argued for the application of military strategy to business and marketing (c.f., Kotler \& Singh, 1981). Military principles and stratagems provide insights on how a firm could succeed when attacking or defending itself from competitors. Therefore, marketing managers should deepen their understanding of and application of key concepts from military strategy and tactics (Kotler \& Singh, 1981).

In previous applications of military strategy to business, the organization was discouraged from taking a customer-centric point of view. One early effort in this area suggested that in order to be successful, modern businesses must concentrate their resources on the conflict which exists between competitors and not on satisfying human needs and wants (Ries \& Trout, 1986). Other early researchers echoed this approach by suggesting that if military strategy were to be used, the primary focus must be on the competition (Cohen, 1986) and that these strategies must be carefully determined before tactics are developed (German, Donahue, \& Schnaars, 1991). Research concerning marketing and military strategy has since consisted primarily of various applications of the strategies described by Sun Tzu and his followers (c.f., Rarick, 1996; MacDonald \& Neupert, 2005; Tsang \& Lee, 2002).

From a tactical perspective, however, marketing managers could use a variety of military strategy lessons, such as guerilla warfare, to focus more closely on satisfying customer needs (c.f., French \& Harris, 1982; Levinson, 1985). Such tactics are generally not very expensive; small to mid-sized firms can use them to influence customers and gain competitive advantage (Levinson, 1985). Further, these tactics are easy to understand and apply across a variety of situations. For example, the writings of Mao Tse-Tung and Che Guevara provide useful insights into how to meet the needs of consumers and how to fend off competition (French \& Harris, 1982). Indeed, the usefulness of these historical principles to today's business problems should not be dismissed:

the worth of this material lies not in profound new insights unveiling shortcuts to success. Just the opposite is the case. The writings concentrate on points so vital and basic to the crux of sales management that those ideas are often considered too pedestrian to be mentioned in scholarly texts on the subject (French \& Harris, 1982: 9).

\section{The Benefits of a Military Strategy Approach}

We have found that incorporating key principles of military strategy into the marketing strategy course increases the extent to which students understand the range of strategic options that are available to them as marketing decision makers. There have also been two additional benefits to 
this approach. First, this approach fits well within the rubric of the new Holistic Marketing Concept which proposes that the function of marketing is to exert a broad and multi-dimensional positive impact on society (c.f., Kotler \& Keller, 2012). Second, this approach addresses a key concern of AACSB International to provide timely and relevant business education to prepare students for the rigors of competing in the global economy.

\section{The Holistic Marketing Concept}

The newly conceptualized Holistic Marketing Concept is based on the notion that because the marketing function is the key interface between the organization and the external world, it has a unique obligation to impact many dimensions of the organization's functions. Specifically, this "marketing is everything" approach suggests that there are various, complex roles of marketing, including: internal marketing, integrated marketing, relationship marketing, and performance marketing (Kotler \& Keller, 2012). In examining Figure 1 below, it is easy to see that a broader understanding of key military strategy principles, with a strong emphasis on the context of history and geography, can impact each of the four dimensions of the new Holistic Marketing Concept.

Figure 1:

Competency in Military Strategy

Can Benefit Each Dimension of the Holistic Marketing Concept

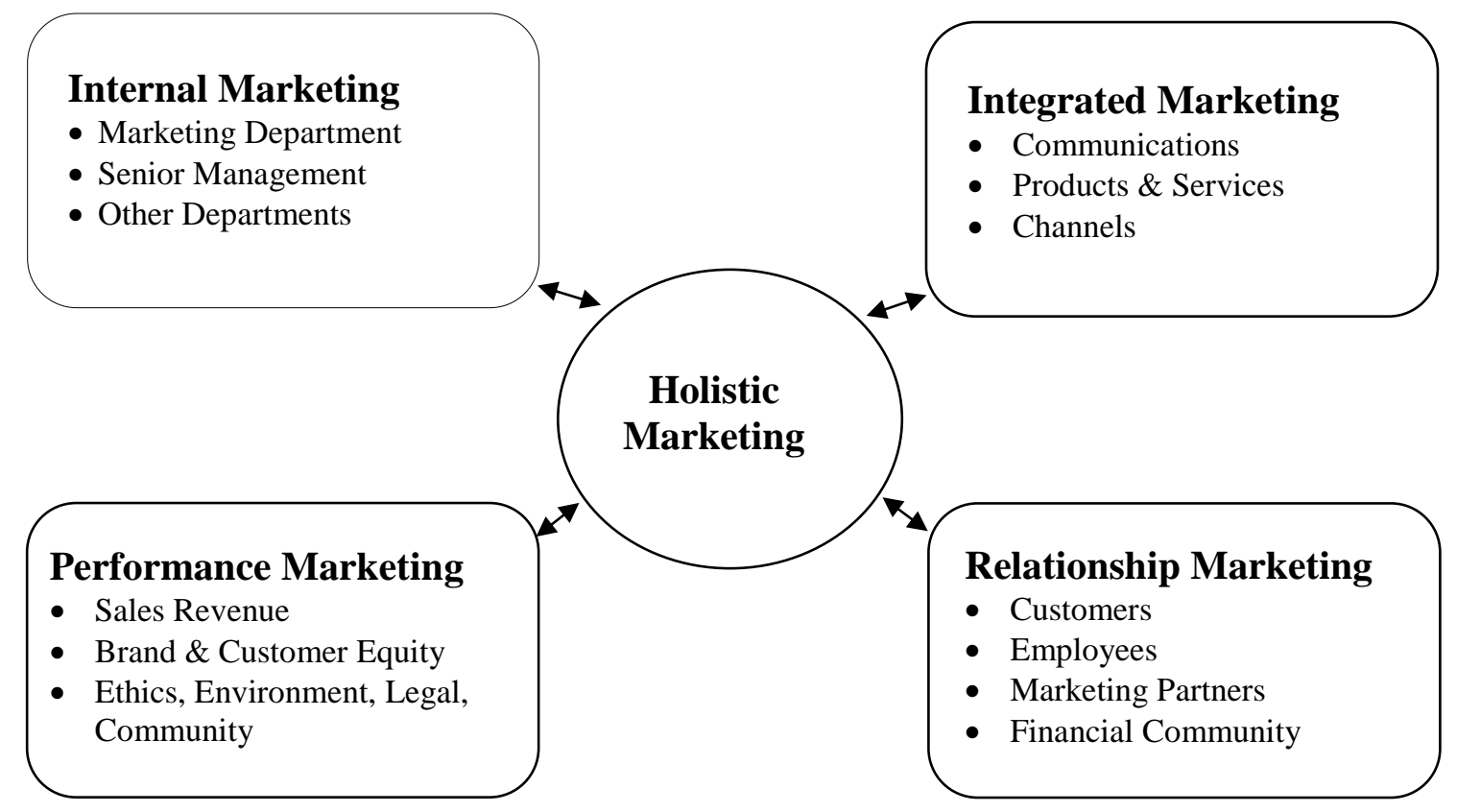

Adapted from Kotler \& Keller, 2012: 18-24.

In the internal marketing dimension of the Holistic Marketing Concept, military strategy proficiency can inform the creation of the mission statement as well as organizational objectives, strategies, and tactics. Further, knowing about previous historical examples of how business 
leaders have tackled various decisions can also give students an important edge when they tackle similar issues (Bussiere, 2005; Petkus, 2010). Seamless integration of efforts is the key defining feature for the integrated marketing dimension. Here, military strategy proficiency can provide students with a range of tools available to carefully coordinate their efforts in delivering value to customers. In the relationship marketing dimension, organizations need to efficiently use resources to create and develop deep, lasting connections with other key stakeholders. In order to develop these strong relationships, it is imperative to have a deep understanding and knowledge of the capabilities and resources of these stakeholders. Knowledge of military strategy provides a key benefit here; even novice military strategists know the adage that it is important to "keep your friends close, but keep your enemies closer." Finally, for the performance marketing dimension of the Holistic Marketing Concept, students of military strategy need to be able to assess the full range of financial and non-financial risks and benefits to the organization. A military strategy approach could foster a deeper understanding of the variety of risks and benefits that accompany a given decision.

\section{AACSB Focus on Innovation, Impact, and Engagement}

Long before AACSB International was founded, business academicians suggested that the role of a business school education was not to just provide a depth of knowledge and expertise in the operations of a business, but to also provide a strong liberal arts education and the skills necessary for independent decision making (Devane, 1943). More recently, AACSB has developed a set of standards for business schools that focus on three main pillars: innovation, impact, and engagement (AACSB International, 2013). Recognizing the importance of the new economic realities, technology, and global focus of businesses today, these standards were developed to help business schools become key partners in preparing future business leaders. The first pillar of focus, innovation, suggests that business schools should promote strong adherence to academic excellence and continuous quality improvement, but also allow enough flexibility in their approaches for creativity and innovation (AACSB International, 2013). The marketing strategy course described herein is certainly innovative and creative in its approach. It requires a faculty member to move beyond the materials that are provided by the textbook publisher and identify other materials that would provide a depth and breadth of understanding. Further, this course forces students to be creative and innovative; using the same methods that led to success in other business classes will not necessarily translate to success in this course. The second pillar is impact and emphasizes the importance of business schools making a difference to the broader community, businesses, and the overall theory and practice of management education and business worldwide (AACSB International, 2013). The marketing strategy course that is advocated here provides students with the ability to positively impact their own organizations through increased knowledge and understanding of the variety of options that are available to them as well as the broader ramifications of their decisions. This will allow them to more effectively reach their consumers, forge relationships with key business partners, and influence other stakeholders. Finally, the last pillar of the AACSB standards is engagement, which emphasizes the importance of establishing a meaningful intersection between academics and the business profession so that graduates of business schools will be fully prepared to lead "meaningful professional, social, and personal lives" (AACSB International 2013: 3). By using a military strategy focus in the marketing strategy course, we believe that students will be less likely to make decisions as if they were in a bubble; instead, they are much more likely to understand the nuances of how a variety of stakeholders could be impacted by a particular 
decision. This increased depth of understanding will likely lead to better engagement with stakeholders such that they will be treated as key partners in the process rather than as outsiders with conflicting agendas. See Figure 2 below for a depiction of how a military strategy focus can exist at the intersection of AACSB's 3 pillars of focus.

Figure 2:

The Military Strategy at the Intersection of the New AACSB Standards



\section{Military Strategy \& The Marketing Strategy Course}

One motivation for the creation of this marketing strategy course was that the authors noticed that course textbooks and other materials provided by publishers presented the course material such that it was filtered to specifically apply to marketing and other business related topics. Students did not have to expend any effort to understand how a case, text, or reading applied to business because the work of applying it was already completed by the textbook author or publisher. The problem of historical and geographical illiteracy among our students made this an even bigger problem; many students simply couldn't make the connections because they didn't have the context in which to do so. Because marketing strategy is generally considered the "capstone" class in the marketing curriculum, it was especially important to forge some of these connections to the broader global environment, hone their business skills, and further develop their critical thinking and decision making abilities.

\section{The Course}

We have found that this course is best structured via a single 150-180 minute class period per week because it allows for greater depth and more probing discussions. During the class period, the instructor and students share the responsibility of presenting and examining the course material which includes an introductory lecture by the instructor, a "Quote of the Day" presentation by two students, and several longer, in-depth individual student presentations on military strategy/history books that they were assigned at the beginning of the semester.

During the first class meeting, a disclosure is made to students that the course will contain a significant liberal arts component and that a substantial amount of time during the course will be 
spent studying historical military commanders and the strategies they used in war. An informal survey of students is conducted which consistently reveals a significant deficit in student knowledge regarding history, military history, and geography. Finally, each student is assigned an individual book which will later be analyzed and presented to the rest of the class.

Beginning with the second class period, discussion of specific time periods and their representative strategies commences and the topics for discussion and analysis progresses chronologically to the present day via several specific time periods to demonstrate to the students the timelessness and universality of certain strategies and tactics. The time periods discussed in the course are as follows:

- Ancient China and Japan

- Classical, Medieval Period, and Mongols

- U.S. Revolutionary War

- U.S. Civil War

- World War II

- Propaganda, Psychological Warfare, Guerrilla Warfare, and Modern Wars

By having the course evolve in a chronological manner as the semester progresses, students are provided not only with a review of world history and culture but are also able to gain an appreciation of four important facts. First, they are able to see how strategies evolved over time and were applied by the great military commanders of history. Second, they are able to see the spontaneous appearance of nearly identical strategies in different parts of the world which had little or no interaction with one another. For example, the first translation of Sun Tzu's Art of War into a European language (French) occurred in 1772. Students are left to ponder whether George Washington was in some way able to see this translation or whether he independently developed and used remarkably similar strategies during the U.S. Revolutionary War. Conundrums such as these fascinate students and cause them to deeply think about and reflect upon the course material. Third, when students are required to apply this new-found knowledge to business, it results in a greater depth of critical thinking and understanding. Finally, while preparing their papers and presentations, students are forced to increase their historical and geographical literacy in order to put their work into the proper context.

Through this use of applied history, the marketing strategy goals of the course are also achieved, while at the same time, geographical and historical knowledge is increased. Although students are supplied with dates, places, and personalities, they understand that all of the information has to be processed with regard to its potential application to marketing and business disciplines. This distinction is critical in order to prevent students from marginalizing the information as irrelevant to their primary course of study as they sometimes do for some of their GenEd requirements.

Based on several semesters of offering the course, the authors have been successful at moving nearly all students (including those who claim to "hate history" at the beginning of the course) to see the benefits of this approach to their business careers. One of the most rewarding parts of teaching the course is watching when students suddenly "get it" and begin applying the strategies examined in class to other classes and even to their personal lives. 


\section{Student Assessment}

During the course, students in the class read approximately 2,000 pages in four books (three common books and one individually assigned book). In addition, each student is required to give three presentations which must engage the rest of their peers in the audience as an individual, as a member of a duet or trio, and as a member of a large group. Students are also required to complete several short (5-8 pages each) papers applying a specific military strategy to marketing and identifying specific business examples that illustrate those strategies. The purpose of all these assignments is to compel students to develop the skills necessary to analyze and then apply the unfiltered details of military strategy to a variety of complex marketing problems. A common requirement for all assignments in the course is that the students locate and provide specific marketing/business examples for a given military strategy. This results in increased student knowledge of a wide range of industries and business entities.

To assess group performance, students are evaluated as members of a small group of 2-3 students via short presentations on a "Quote/Speech of the Day." Further, to assess the ability of students to work with the group under time pressures, the quotes are provided to students one week before the assigned presentation. Each small group is then required to prepare a 10 minute presentation and lead a class discussion lasting an additional 10 minutes. Students are required during their presentation to explain the historical context of the quote or speech, explain how the quote or speech applies to marketing, connect it to material that has already been discussed in class, and provide several specific real world business examples that illustrate use of the quote.

To assess individual performance, each student must conduct an analysis of a book on military strategy or history. After reading their book, students are required to make a 15 minute individual presentation on the book and also lead a 10 minute class discussion. Further, each student is required to submit a written review of the book with a thorough and specific discussion of the book's applicability to marketing.

The final project is an in-depth focus on a specific military leader from history and consists of a substantial written (minimum 30 pages) project and oral presentation which is assigned to student teams of 4-6 members. The assignment includes:

1. Preparation of an annotated bibliography of all sources with a minimum of $15-30$ sources.

2. Thorough background research on the history and biographical background of the assigned military leader.

3. Thorough background research on the military leader's strategies, tactics, character, personal strengths/weaknesses and leadership skills.

4. Thorough analysis of the strategies of one or more of the assigned leader's opponents.

5. Explanation of why the assigned leader's strategies were effective/successful against his opponents (or why they weren't).

6. Summary of the assigned leader's strategies into a comprehensive "guidebook" that business leaders could use. 
7. Selection of a business leader (current or historical) that is then used to assess the benefit of the guidebook via an analysis and critique of the selected business leader's actions, strategies, etc.

8. Delivery of a 20 minute formal presentation on the assigned leader.

In the end, we typically find that although students are generally dissatisfied with the large amount of work required for the course, they do participate with a deeper level of engagement than what is typically found in their other classes. End-of-semester evaluations of faculty performance by the students have been excellent, as is evidenced by means that are above those of the department, college, and university (see Table 1 below).

Table 1:

5 Semester Average of End-of-Semester Course Evaluations

\begin{tabular}{l|c}
\hline \multicolumn{1}{c|}{ Item } & Score \\
\hline Overall Quality of Instructor* & 5.68 \\
Department Mean & 5.10 \\
College Mean & 4.80 \\
University Mean & 5.00 \\
Delivery Mean $^{\mathrm{a}}$ & 94.58 \\
Preparation Mean $^{\mathrm{b}}$ & \\
& 94.38 \\
\hline
\end{tabular}

* The first four scores are on a 1-6 point scale, with $6=$ outstanding and $1=$ poor. The second two scores are on a 100 -point scale.

${ }^{a}$ The Delivery Mean is a combined score of several items relating to course delivery, engagement, and effectiveness.

${ }^{b}$ The Preparation Mean is a combined score of several items relating to the course materials, assignments, and faculty preparation/expertise.

Student comments further illuminate the conclusion that although the class was a lot of work, the tasks to be completed in class each added to fulfill a specific learning objective. Indeed, there was very little "busy work" perceived by the students. Further, students noticed that they were engaging with the material much more deeply and comprehensively than material from other classes. A summary of student comments across 5 semesters revealed that although there was skepticism at first about the material and approach, in the end, they recognized the value of the educational experience.

Table 2:

5 Semester Summary of Student Comments

Initial Skepticism

- I learned a lot despite weird syllabus/course assignments. There was method to the madness.

- $\quad$ By the end of the semester, I liked how it all fit together. 
- I thought I would hate the whole "war strategies as related to business," but I ended up liking it.

\section{Dissatisfaction with Work Load}

- $\quad$ There was a lot of reading. However, since it was interesting material for me, I don't mind.

- Final paper is too long!

- A LOT of reading.

\section{Satisfaction with Novel Approach}

- It is interesting and different to use history as the basis of this course and applying history to business and marketing.

- Very nice way to get us to learn without being "just another business course."

- Overall, I liked the class. It was something completely different from my other classes and I also learned a new way of looking at marketing.

\section{Recognition of Skill Improvement}

- This class was really helpful to me in regards to growing as a person and feeling comfortable presenting to my peers.

- The material was interesting \& showed how a lot can be learned from studying the past. I was also able to utilize points from my individual presentation in interviews.

- Gives you great group \& presentation practice. Requires you to relate old war tactics to new businesses.

- I believe I am a better writer because of this class.

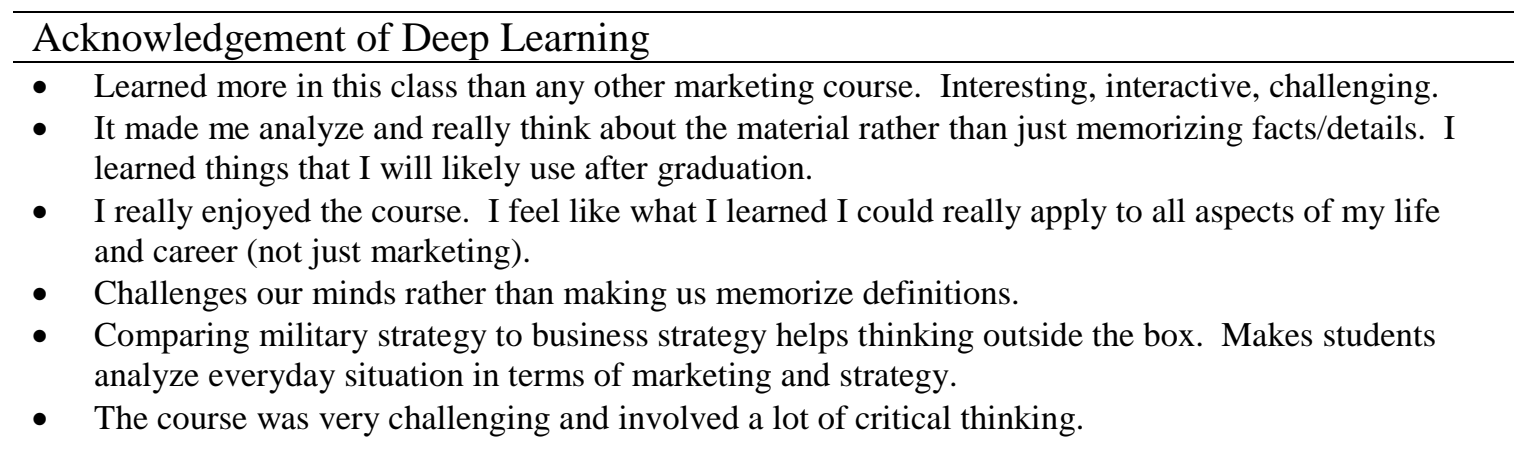

\section{Conclusion}

It is important to emphasize that military history, with its heavy reliance on contextual history and geography, is the vehicle by which we attempt to improve student performance of key marketing strategy concepts. Our main goal is to forge a deeper understanding of marketing strategy and encourage the application of key strategic principles across a wide variety of global contexts and situations. Today, many business students are graduating with knowledge deficiencies in history and geography. Although AACSB International advocates that the business programs it accredits foster global awareness, the global awareness currently gained by a substantial number of undergraduate business students during their college careers is likely superficial in nature. Students should leave the university fully prepared to make positive contributions to society as informed voters, careful public policy makers, and judicious business decision makers (Morin, 2012). The marketing strategy course described herein will not solve all of the problems of historical and geographical illiteracy - and it is certainly not designed to 
do this. However, we believe that the course can provide a deeper understanding of the application of marketing strategy because it addresses some deficiencies in historical and geographical knowledge.

This course offering blends liberal arts and business information to provide students with the skills needed for marketing strategy as well as historical and geographical contexts necessary to improve their understanding of the problems. Upon completion of the course, students begin to understand how interconnected human knowledge is and the importance of obtaining knowledge and ideas from outside the business school. They also come to the realization that, although strategy evolves over time and is applied differently due to varied situational factors, it never strays far from its core principles. Importantly, the course's holistic approach equips students with skills that are needed to be competitive in the global economy. 
ISSN: 2690-8220

\section{References}

AACSB International (2013). Eligibility procedures and accreditation standards for business accreditation. AACSB International - The Association to Advance Collegiate Schools of Business, January 18, Tampa, FL.

Ahmed, Z. V. \& Krohn, F. B. (1994). The symbiosis of liberal arts and international business. Journal of Education for Business, 64(4), March/April, 199-203.

American Academy of Arts \& Sciences (2013). The Heart of the Matter. The American Academy of Arts \& Sciences, Cambridge, MA.

Berry, G. R. \& Workman, L. (2007). Broadening student societal awareness through service learning and civic engagement. Marketing Education Review, 17(3), 21-32.

Brint, S., Proctor, K., Mulligan, K., Rotondi, M. B., \& Hanneman, R. A. (2012). Declining academic fields in U.S. four-year colleges and universities, 1970-2006. The Journal of Higher Education, 83(4), July/August, 582-613.

Carr, D. L. (2005). U.S. foreign policy and a geographically challenged U.S. citizenry. Journal of Geography, 104(1), January/February, 41-42.

Chung, E., Molnar, K., \& Gilbertson, J. (2011). Oil and water? Business education in a liberal arts setting. Insights to a Changing World Journal, 4, December, 137-148.

Cohen, W. A. (1986). War in the marketplace. Business Horizons, 29 (2), March/April, 10-20.

Colby, A., Ehrlich, T., Sullivan, W. M., \& Dolle, J. R. (2011). Rethinking Undergraduate Business Education: Liberal Learning for the Profession, 1st ed. The Carnegie Foundation for the Advancement of Teaching, San Francisco: Josey-Bass.

Davis, L. J. (2005). The perils of academic ignorance. Chronicle of Higher Education, 51(37), B13-B14.

Devane, W. C. (1943). American education after the war. Yale Review, 33(1), Autumn, 31-46.

Ewest, T. \& Kliegl, J. (2012). The case for change in business education: How liberal arts principles and practices can foster needed change. Journal of Higher Education Theory and Practice, 12(3), 75-86.

French, W. A. \& Harris, C. E., Jr. (1982). Can our salesforce managers learn from guerrilla tactics? Journal of Personal Selling \& Sales Management, 2(2), November, 8-13.

German, M., Donahue, D. A., Jr., \& Schnaars, S. P. (1991). A chink in marketing's armor: Strategy above tactics. Business Horizons, 34(2), March-April, 74-78.

Gross, M. L. (1999). The Conspiracy of Ignorance: The Failure of American Public Schools. New York: Harper Collins.

Hess, F. M. (2008). Still at risk: What students don't know, even now. A Report from Common Core. Washington, DC: Common Core.

https://commoncore.org/maps/documents/reports/CCreport_stillatrisk.pdf, accessed 1 January 2014.

Hutton, T. S. (2006). The conflation of liberal \& professional education: Pipedream, aspiration, or nascent reality? Liberal Education, 92(4), Fall, 54-59.

Kantrow, A. M. (1986). Why history matters: A roundtable discussion on the value of having managers study history and a graduate school of business administration teach it. Harvard Business Review, Jan-Feb, 81-88.

Kliegl J. A. \& Weaver, K. D. (2012). Business education and liberal learning. AAC\&U Peer Review, 14(2), Spring, 28-30.

Kotler, P. \& Keller, K. L. (2012). Marketing Management, $14^{\text {th }}$ ed. Upper Saddle River, NJ: Prentice Hall. 
Kotler, P. \& Singh, R. (1981). Marketing warfare in the 1980s. The McKinsey Quarterly, 2, Summer, 62-81.

Levinson, J. C. (1985). Guerrilla Marketing. Boston: Houghton-Mifflin Company.

MacDonald, J. B. \& Neupert, K. E. (2005). Applying Sun Tzu's terrain and ground to the study of marketing strategy. Journal of Strategic Marketing, 13(4), December, 293-304.

Morin, K. M. (2012). Geographical literacies and their publics: Reflections on the American scene. Progress in Human Geography, 37(1), 3-9.

National Geographic, Roper Public Affairs (2006). Final Report National Geographic - Roper Public Affairs 2006 Geographic Literacy Study. Washington (DC): The National Geographic Education Foundation.

Petkus, E. (2010). Historical perspectives in marketing education: Justification and implementation. Journal of Marketing Education, 31(1), April, 64-74.

Pierson, F. C. (1959). The Education of American Businessmen: A Study of University-College Programs in Business Administration. New York: McGraw-Hill Book Company, Inc.

Rarick, C. A. (1996). Ancient Chinese advice for modern business strategists. SAM Advanced Management Journal, 61(1), Winter, 38-43.

Ries, A. \& Trout, J. (1986). Military Marketing Warfare: A Comparative Review of the Use of Combative Philosophies and Terminology. New York: McGraw-Hill Book Company.

Smith, G. E. (2007). Management history and historical context: Potential benefits of its inclusion in the management curriculum. Academy of Management Learning \& Education, 6(4), December, 522-533.

Stewart, D. W. (2010). The purpose of university education. The Psychologist-Manager Journal, $13,244-250$.

Stewart, I. (2004). Can professional studies be included in the liberal arts curriculum? Innovative Higher Education, 29(1), April, 67-81.

Thompson, D. M. \& Grubbs, J. H. (1998). Embracing cultural geography: An army imperative. GeoJournal, 44(1), 35-41.

Tsang, Y.S. \& Lee, S. F. (2002). A study on Sun Pin's art of business management strategies matching the MBNQA criteria for business competitiveness. Integrated Manufacturing Systems, 13(6), 386-407.

Walker, J. (2009). Language and culture requirements in international business majors at AACSB-accredited business schools. Journal of Teaching in International Business, 20, 293-311.

Wright, N. D. \& Larsen, V. (2012). Every brick tells a story: Study abroad as an extraordinary experience. Marketing Education Review, 22(2), 121-142. 